\title{
Features of Streets and Urban Roads Greening in Ukraine and other Countries of the World
}

\author{
Iryna Tkachenko1, Tetyana Lytvynenko', Dmitry Prusov², Lina Hasenko'* \\ ${ }^{1}$ Department of Roads, Geodesy, Land Management and Rural Buildings, Institute of Architecture and Construction, \\ Poltava National Technical Yuri Kondratyuk University, Pershotravnevyi Avenue, 24, Poltava, 36011, Ukraine \\ 2 Department of Construction Engineering and Information Technologies, Institute of Innovative Education, \\ Kyiv National University of Construction and Architecture, Education street, 4, 03037 Kyiv, Ukraine \\ * Corresponding author, e-mail: lin02011@meta.ua
}

Received: 15 September 2019, Accepted: 03 December 2019, Published online: 30 March 2020

\begin{abstract}
The work is devoted to placement of streets and urban roads greening elements. The statistics of the road traffic fatalities rate as a result of ride on obstruction, in particular a tree in Ukraine, Poland, the USA, Denmark, have been analyzed. An unsatisfactory situation in Ukraine was confirmed, where the accident rate on roads with a fatal outcome is almost 10 times higher than in the safest countries of the world. The main functions of the streets and urban roads greening elements are generalized. There are: environmental protection (noise absorption, air purification from exhaust gases and pollination); decorating (creation of space for satisfaction of esthetic requirements of a person); accentuating; barrier etc. The greening elements of Ukraine streets and urban roads are classified and compared with the classifications of Queensland (Australia) and Poland. Current placement of greening elements in Poltava (Ukraine) streets was analyzed and the main disadvantages of placing greening elements were revealed. The normative requirements for the street and urban road greening elements placement in Ukraine, Queensland (Australia), Poland, Sweden, Denmark have been analyzed. Existing placement of the street and urban road greening elements in countries with high level of traffic safety were researched and the ways of improvement of existing street greening in Ukraine was found.
\end{abstract}

Keywords

greening, street environment, tree, roadside vegetation, urban road

\section{Introduction}

According to the Accident statistics in Ukraine during 8 months in 2017, crashes with obstacle make up $10 \%$ of all and $12 \%$ of crashes with fatalities (Department of Information and Analytical Support of the National Police of Ukraine, 2017). The obstacles at which most often bump in Ukraine (with fatalities) are trees and reinforced concrete posts (Figs. 1 and 2).

In Poland in 2013 trees accounted 6 percent of the total number of road accidents, $14 \%$ of which are fatalities. Crashes with trees are characterized by a very high degree of severity. 23 people are die in average 100 cases (Jermołowicz, 2016).

In USA crashes with trees accounted for nearly $1.9 \%$ of all, 46 percent of which are fatalities (Fitzpatrick, 2013). According to the Roadside Design Guide (AASHTO, 2006) single vehicle crashes with trees account for nearly $25 \%$ of all the fatal crashes annually and result in the deaths of

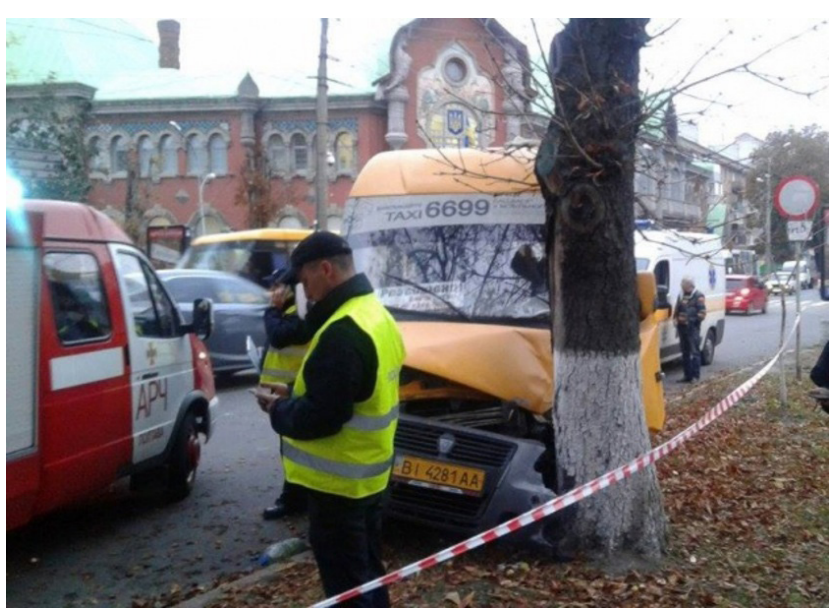

Fig. 1 A minibus crashed into a tree, Sobornosty Street, Poltava, Ukraine approximately 3,000 persons each year. Statistics also show that from 2007 through 2009 there were over 11,400 fatalities that resulted from crashes into trees (Parwathaneni, 2016). 


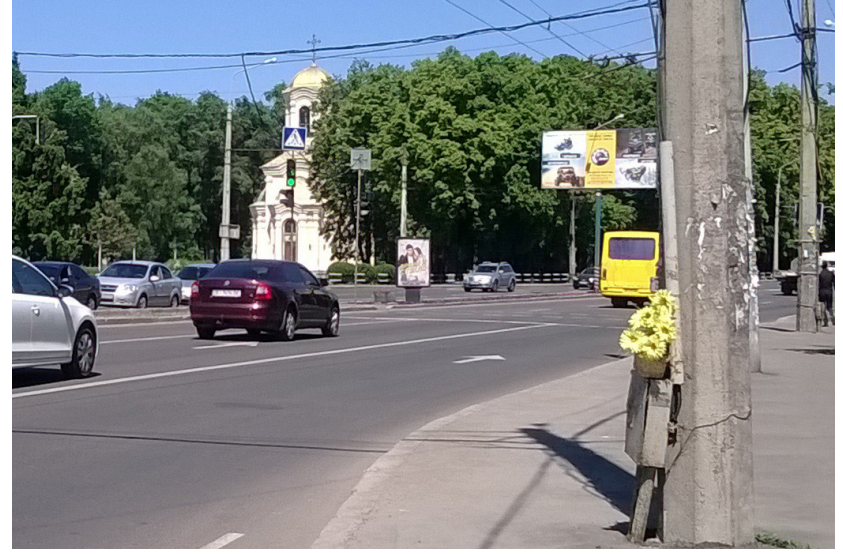

Fig. 2 Reinforced concrete post near the roadway, European Street, Poltava, Ukraine

In Denmark, 70 percent of serious tree-related crashes occurred within $3 \mathrm{~m}$ from the roadway. One third of crashes happened to the left of the traffic direction, and two thirds crashes happened to the right of the traffic direction. Also, the falling of branches or whole trees on a roadway or on a vehicle during a strong wind (a storm) are often marked, which can block road traffic and crash the cars or lead to fatal crashes (Fig. 3).

Another problem with streets greening is that often the vegetation dying due to unsatisfactory ecological conditions (Tong et al., 2016), in particular, the gas pollution of the air and salt, which is covered by the roadway in the winter (Fig. 4). It leads to excessive maintenance costs: cutting dry trees and planting new ones.

At the same time, the planting of roadside vegetation has many positive functions (Akbar et al., 2003; Kadir and Othman, 2012), namely: environmental protection (noise attenuation, air purification from exhaust gases and pollination); decorating (creation of space for satisfaction of esthetic human requirements); guidance; barrier and so on.

The functions of roadside vegetation are extensively researching in the world. Khomyak (1990), Babkov (1993) and Ornatskij (1986) (Russian) research the orienting, accentuating and guidance properties of plantations, improving traffic safety using roadside vegetation, and ensuring better inclusion of the road into the landscape.

Sardarov (Belarus) studies the history of development and formation of greening principles, factors contributing to the formation of principles of roadside vegetation location, greening of road structures (Sardarov, 2001).

Noriah Othman (Malaysia) explores roadside tree management for public safety (Badrulhisham and Othman, 2016; Hasan et al., 2016a), tree pruning, tree preservation

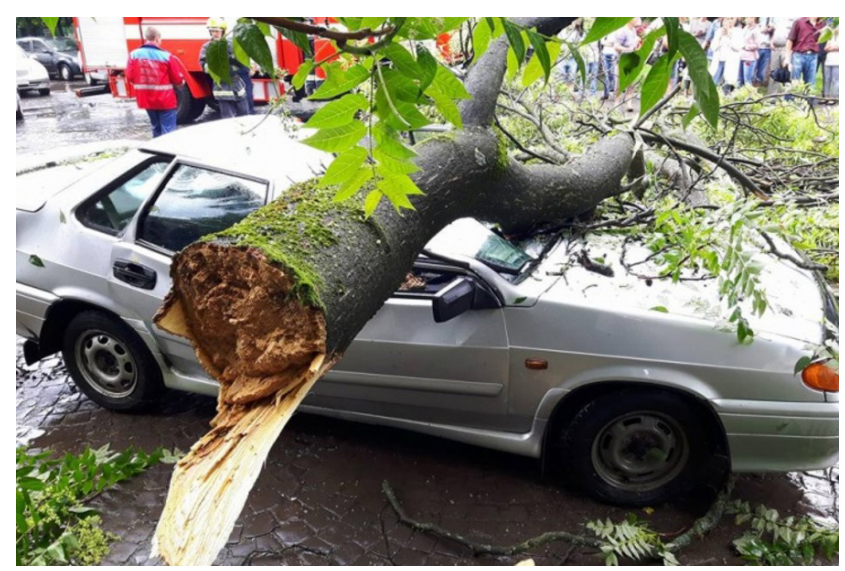

Fig. 3 The tree fell to the car, Vinogradov, Zakarpattia region, Ukraine

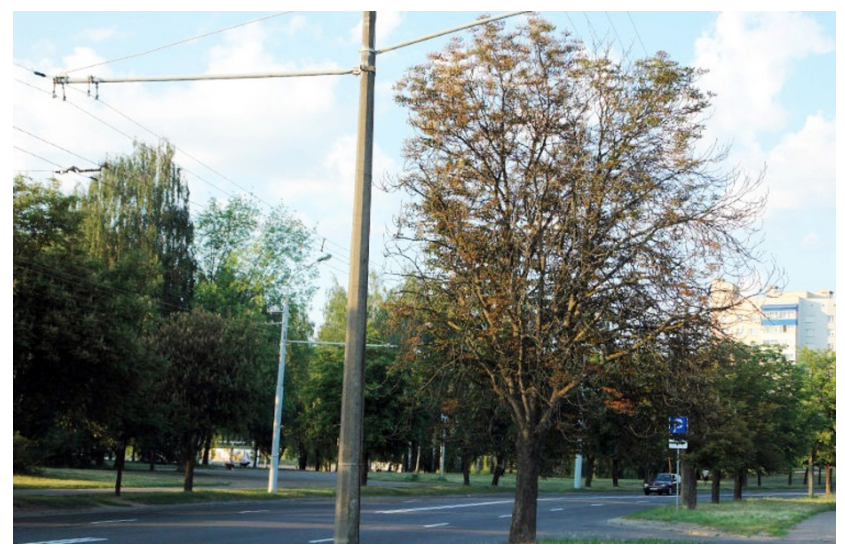

Fig. 4 The dry tree along the street

order, street tree benefits, types of significant street trees (Kadir and Othman, 2012; Badrulhisham and Othman, 2016; Hasan et al., 2016b). He writes that fallen trees is the main reason for the public to lodge complaints, followed by brittle branches, thick branches and leaning tree trunk.

Researchers from United States: Moket al. (2006) and Baldauf (2017) are researching landscape design in the clear zone: effect of landscape variables on pedestrian health and driver safety, near-road air quality. Naderi et al. (2008) writes that drivers drove slower with the presence of trees, people perceived suburban streets with trees as the most safe streets and urban streets without trees as the least safe streets. Parwathaneni (2016) is research the effect of roadside vegetation on driver behavior. Fitzpatrick (2013) writes that the size of the clear zone increased so did the speed at which respondents said they would travel.

The purpose of this work is to identify the features of the placement of greening elements of streets in Ukraine and to compare with countries of the world with a high level of road safety. 


\section{Case study area}

Poltava (Ukraine), as the city in which the authors live, was explored in detail.

To study the foreign experience of street greening, countries with the safest roads were selected.

Having reviewed the statistics of Road traffic fatalities and injuries, rate per million inhabitants (Fig. 5) and rate per 100000 passenger cars according to UNECE Statistical Database United Nations Economic Commission for Europe (UNECE, 2018), the following countries were selected for research: Denmark, Israel, Netherlands, and Spain (Table 1). Also reviewed in the study Poland (a neighboring country with a high traffic safety index) and Queensland (Australia) - 7 Road traffic fatalities rate per 100000 passenger cars in 2015. In these countries were selected cities with population and area similar to Poltava, Ukraine (Table 2).

\section{Classification of roadside vegetation elements}

The elements of roadside vegetation are divided into the following groups: trees, shrubs, grass and flowers, according to the normative literature of Ukraine (Fig. 6).

In accordance with the regulations of Queensland (Australia), the roadside vegetation elements are divided into: Frangible and Non Frangible vegetation (Fig. 7).

Frangible vegetation is the plants with stems equal to or less than $70-100 \mathrm{~mm}$ when measured from $300 \mathrm{~mm}$

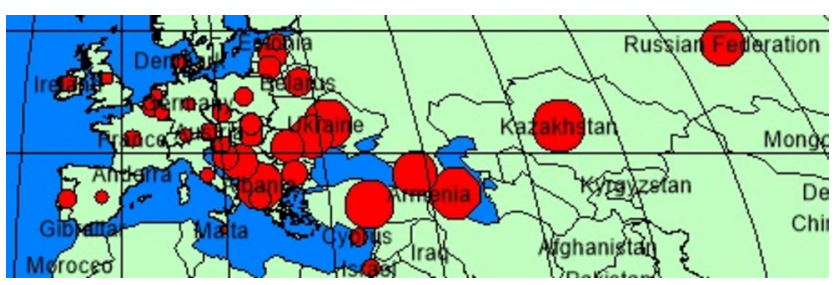

Fig. 5 The Road traffic fatalities rate per million inhabitants

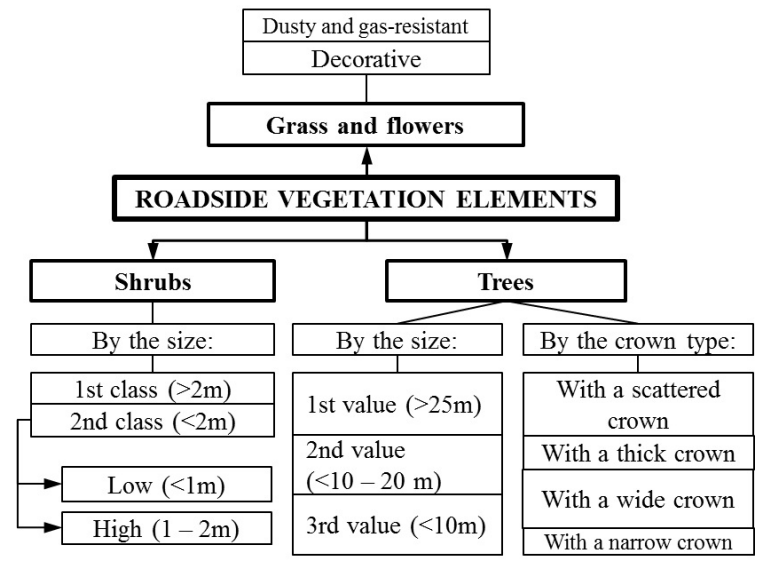

Fig. 6 Classification of roadside vegetation elements in Ukraine above the finished ground level. Groundcovers and shrubs are all generally frangible except for large shrub species exceeding $3.5 \mathrm{~m}$ in mature height. Trees are not considered frangible. Non Frangible vegetation is the plants with stems larger than $70-100 \mathrm{~mm}$ when measured from $300 \mathrm{~mm}$ above the finished ground level. Shrubs species exceeding $3.5 \mathrm{~m}$ in mature height and trees are considered non-frangible (RLM, 2013).

In Poland the trees divided on: the smallest (1st size): height 3.0 - $5.0 \mathrm{~m}$, crown $1.0-3.0 \mathrm{~m}$; the small (2nd size): height $8.0-10.0 \mathrm{~m}$, crown up to $5.0 \mathrm{~m}$; medium (3rd size): height up to $15 \mathrm{~m}$, crown $5.0-8.0 \mathrm{~m}$; very large (4th size): height more than $15 \mathrm{~m}$, crown more than $8.0 \mathrm{~m}$ (Polish Dendrological Society, 2016). Such classification in Poland

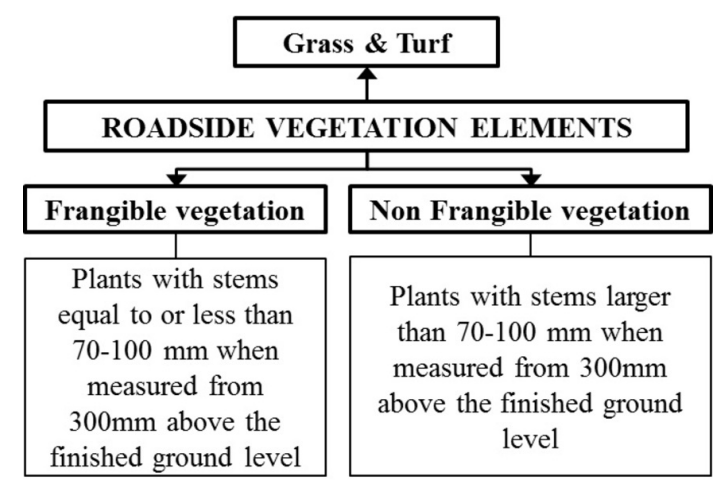

Fig. 7 Classification of roadside vegetation elements in Queensland (Australia)

Table 1 Road traffic fatalities, rate per million inhabitants and rate per 100000 passenger cars by Topic, Measurements, Country and Year (last available value for July 2018)

\begin{tabular}{|c|c|c|c|c|}
\hline No & \multicolumn{2}{|c|}{ Country } & \multicolumn{2}{|c|}{$\begin{array}{l}\text { Road traffic fatalities rate per } \\
100000 \text { passenger cars }\end{array}$} \\
\hline 1 & \multicolumn{2}{|c|}{ Denmark } & \multicolumn{2}{|r|}{7} \\
\hline 2 & \multicolumn{2}{|c|}{ Israel } & \multicolumn{2}{|r|}{12} \\
\hline 3 & \multicolumn{2}{|c|}{ Netherlands } & \multicolumn{2}{|r|}{7} \\
\hline 5 & \multicolumn{2}{|c|}{ Poland } & \multicolumn{2}{|r|}{14} \\
\hline 6 & \multicolumn{2}{|c|}{ Spain } & \multicolumn{2}{|r|}{8} \\
\hline 7 & \multicolumn{2}{|c|}{ Ukraine } & \multicolumn{2}{|r|}{71} \\
\hline \multicolumn{5}{|c|}{ Table 2 Cities selected for research } \\
\hline No & Country & City & $\begin{array}{l}\text { Area, } \\
\mathrm{km}^{2}\end{array}$ & $\begin{array}{l}\text { Number of residents } \\
\text { (in thousands) }\end{array}$ \\
\hline 1 & Denmark & Aarhus & 91 & 260 \\
\hline 2 & Israel & Haifa & 64 & 274 \\
\hline 3 & Netherlands & Utrecht & 99 & 300 \\
\hline 5 & Poland & Bialystok & 102 & 295 \\
\hline 6 & Spain & Vigo & 109 & 297 \\
\hline 7 & Ukraine & Poltava & 103 & 292 \\
\hline
\end{tabular}


more closely divides trees than in Ukraine, which affects the choice of their placement (Fig. 8).

\section{Assessment of the current state of streets and urban roads greening in Ukraine}

A detailed survey of the streets and urban roads greening in Poltava, Ukraine, was conducted.

City Poltava is considered one of the greenest cities in Ukraine. The streets of the city level (10 pcs.) and the streets of the district level (30 pcs.) were considered (Fig. 9).

Regardless, the main disadvantages of placing roadside vegetation elements were revealed: normative distances between roadside vegetation elements and roadway or sidewalks are non-observance; the crown of trees touches the transmission lines; streets without greening (or part of street without greening); the visibility of road signs is obstructed; vegetation above $0.5 \mathrm{~m}$ within the visibility triangle at the intersections (Table 3).

Main streets of city significance have less disadvantages in placing roadside vegetation elements, if have analyzing the dependence of the presence of disadvantages on the street category.

In particular, the disadvantages have almost no in trees placement along the main streets of the city: Velikotyrnovska and European, only a few isolated trees are closer than $3 \mathrm{~m}$ from the edge of the roadway.

The lower the category of street, the more often there are problem areas (Table 4). The following streets: Patriarkha Mstyslava, Olesia Honchara, Shevchenka, Dmytra Koriaka, Kozaka Volodymyra, Stritenska, Pushkina have the most violations of regulatory requirements. On which almost all the trees are planted at a distance of $0.5-2 \mathrm{~m}$ from the edge of the roadway, some trees have a diameter of a trunk about $1 \mathrm{~m}$ and the edge of the trunk is placed very close to the roadway, and some is on the roadway.

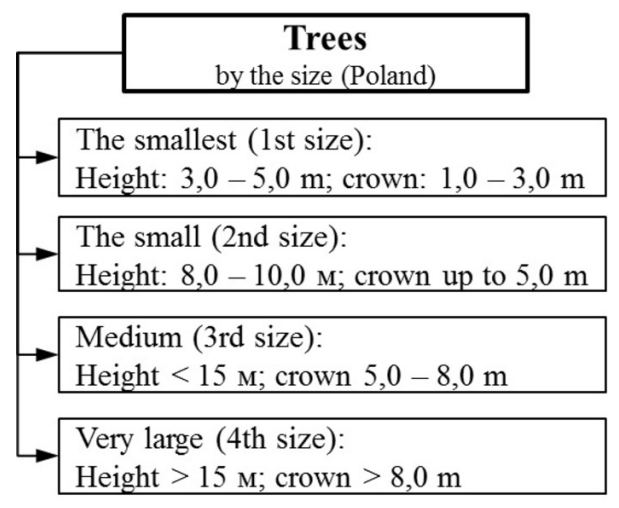

Fig. 8 Classification of the trees by the size in Poland
Depending on the time of planning and construction of the city's districts and sub-districts, mainly the streets with disadvantages in the placement of roadside vegetation elements are found in the central (historical) part of the city and in sub-districts that was building in the 50-60's of the 20th century. There are also disadvantages in newer sub-districts (built in the 80's of the twentieth century) where the streets expanded using the strip of greening. Some trees have a diameter of a trunk about $1 \mathrm{~m}$ and the edge of the trunk is placed very close to the roadway, and some are on the roadway.

An interesting situation is on the Zinkivska street, Poltava, on which was built recently the first bikeway. Along the street are planted acacia trees (distance from roadway less than the normative). The crown extending beyond the roadway almost completely does the bikeway

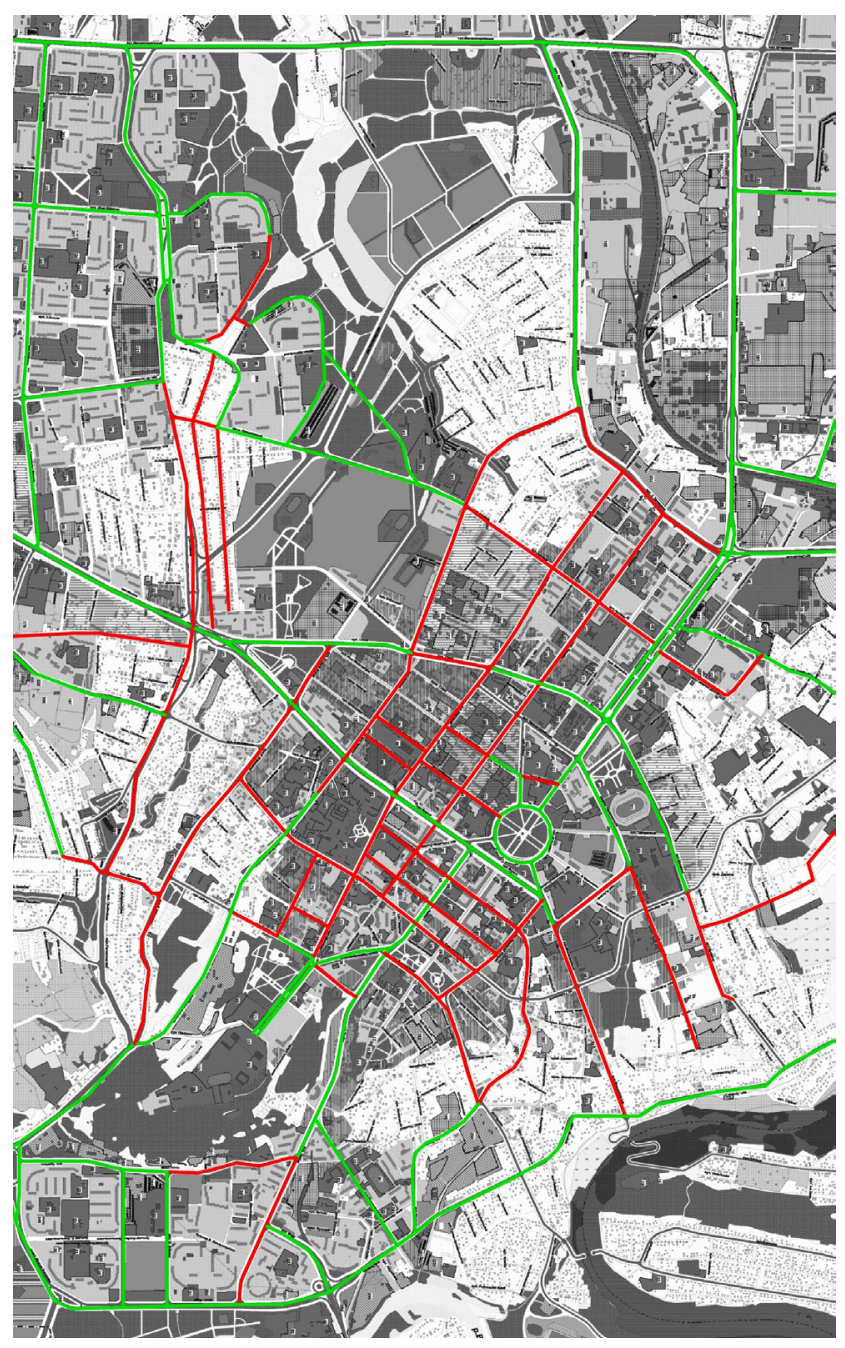

Fig. 9 Surveying the streets of Poltava city (Ukraine) for the presence of disadvantages in placing roadside vegetation elements: RED LINEstreets with disadvantages, GREEN LINE- streets that mostly have not disadvantages 
Table 3 The main disadvantages of roadside vegetation (for example Poltava, Ukraine)

\begin{tabular}{|c|c|c|}
\hline No & Name of disadvantage & Illustration of disadvantage \\
\hline 1. & $\begin{array}{l}\text { Normative distances } \\
\text { between roadside vegetation } \\
\text { elements and roadway } \\
\text { or sidewalks is non- } \\
\text { observance } \\
\text { (Type } 1 \text { ) }\end{array}$ & \\
\hline 2. & $\begin{array}{l}\text { The crown of trees touches } \\
\text { the transmission lines } \\
\text { (Type } 2 \text { ) }\end{array}$ & \\
\hline 3. & $\begin{array}{l}\text { Streets without greening } \\
\text { (or part of street without } \\
\text { greening) } \\
\text { (Type 3) }\end{array}$ & \\
\hline 4. & $\begin{array}{l}\text { The visibility of road signs } \\
\text { is obstructed } \\
\text { (Type } 4 \text { ) }\end{array}$ & \\
\hline 5. & $\begin{array}{l}\text { Vegetation above } 0.5 \mathrm{~m} \\
\text { within the visibility triangle } \\
\text { at the intersections } \\
\text { (Type 5) }\end{array}$ & $=$ \\
\hline
\end{tabular}

inaccessible to bicycle. Therefore, it is important to choose not only the distance of the trees planting and the species of trees, because if you ride a bike close to the crown then you can traumatize by acacia spikes.

A similar situation with the placement of trees is in other cities of Ukraine, in particular in Kiev, Kharkov, Odessa, Lutsk, etc.

By the number of disadvantages the most common is type 1 - trees with a crown more than $4 \mathrm{~m}$ in diameter situated closer than $3 \mathrm{~m}$ to the roadway (Fig. 10), which differ

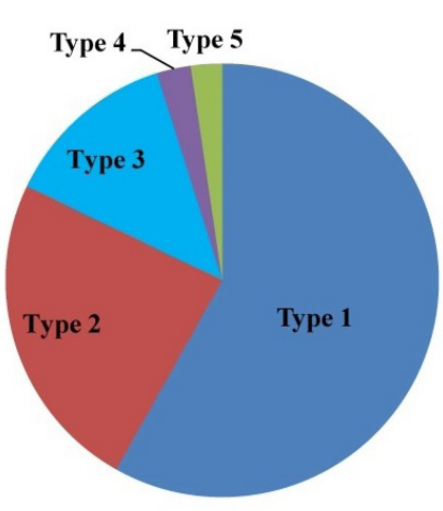
Type 1 Trees closer $3 \mathrm{~m}$,
$\mathrm{dc}>4 \mathrm{~m}$ to $\mathrm{RW}, \mathrm{pcs}$

- Type 2 Crown of trees touches the TL, pcs

- Type 3 Streets without greening $1 \mathrm{pcs}$. tree $\times 50 \mathrm{~m}$

- Type 4 Visibility of road signs is obstructed, pcs

Type 5 Vegetation above $0.5 \mathrm{~m}$ within the visibility triangle, pcs

Fig. 10 Disadvantages of roadside vegetation elements placing in Poltava city (Ukraine)

from the standards and may be the cause of road accident with serious consequences. There are also areas of streets without roadside vegetation, which significantly impairs the quality of air in these areas (pollution by exhaust gases, pollination) and aesthetic perception of the street.

The obstruction of the visibility of road signs is mainly the maintenance problem, namely the disadvantages of trees pruning.

\section{Analysis of normative requirements about the roadside vegetation elements placement}

The next step of this study was analysis of requirements in Ukraine normative documents about the roadside vegetation elements placement and comparison with foreign ones.

To compare the parameters of roadside vegetation elements placing along the streets, the regulatory documents of Ukraine (Ministry of Fuel Energy of Ukraine, 2017), the countries bordering on Ukraine - Poland and the countries of the world with high traffic safety: Queensland (Australia), Sweden and Denmark, were considered. For convenience, the value is summarized and presented in Table 5.

Shrubs of less than $1 \mathrm{~m}$ and the separate tree in the visible zones don't take into account in Poland.

The distance from the edge of the sidewalk or bikeway to the tree in Ukraine is less than in comparable countries. In Ukraine it is $0.7 \mathrm{~m}$, regardless of the size of the tree, and in Sweden it varies from $1 \mathrm{~m}$ to $2.5 \mathrm{~m}$, depending on the size of the tree. In Queensland, this distance should be at least $1 \mathrm{~m}$, and if the trees are above $15 \mathrm{~m}$ and are characterized by the danger of falling branches or seeds, then this distance should be at least $10 \mathrm{~m}$. 
Table 4 Surveying of disadvantages in roadside vegetation elements placing in Poltava city (Ukraine)

\begin{tabular}{|c|c|c|c|c|c|c|c|c|}
\hline \multirow[b]{3}{*}{ № } & \multirow[b]{3}{*}{ Street } & \multirow{3}{*}{$\begin{array}{l}\text { Number } \\
\text { of lines }\end{array}$} & \multicolumn{6}{|c|}{ Number of disadvantages } \\
\hline & & & & Type 1 & Type 2 & Type 3 & Type 4 & Type 5 \\
\hline & & & & $\begin{array}{l}\text { Trees closer } \\
3 \mathrm{~m} \text { to RW }\end{array}$ & $\begin{array}{l}\text { Trees crown } \\
\text { touches the TL }\end{array}$ & $\begin{array}{l}\text { Street without } \\
\text { greening, } \\
\text { tree } \times 50 \mathrm{~m}\end{array}$ & $\begin{array}{l}\text { Visibility of } \\
\text { road signs is } \\
\text { obstructured }\end{array}$ & $\begin{array}{l}\text { Vegetation above } \\
0.5 \mathrm{~m} \text { within the } \\
\text { visibility triangle }\end{array}$ \\
\hline \multicolumn{9}{|c|}{ Main streets of city significance } \\
\hline 1 & Velykotyrnivska & 4 & 4.1 & 2 & 0 & 0 & 0 & 0 \\
\hline 2 & Yevropejska & 6 & 6 & 5 & 5 & 0 & 0 & 2 \\
\hline 3 & Zinkiska & 6 & 1.7 & 0 & 0 & 0 & 0 & 0 \\
\hline 4 & Ivana Mazepy & 4 & 1.8 & 0 & 0 & 0 & 0 & 0 \\
\hline 5 & M.Biruzova & 6 & 2.3 & 0 & 0 & 3 & 0 & 0 \\
\hline 6 & Myrustr. & 4 & 1 & 0 & 0 & 0 & 0 & 0 \\
\hline 7 & Myruav. & 6 & 1.4 & 2 & 0 & 6 & 0 & 0 \\
\hline 8 & NebesnoySotni & 4 & 2.8 & 12 & 10 & 10 & 0 & 0 \\
\hline 9 & Polovka & 4 & 2.4 & 3 & 2 & 10 & 0 & 0 \\
\hline 10 & Sobornosti & 6 & 1.7 & 0 & 0 & 0 & 0 & 0 \\
\hline To & & & 25.2 & 24 & 17 & 29 & 0 & 2 \\
\hline & for $1 \mathrm{~km}$ & & & 0.95 & 0.67 & 1.15 & 0 & 0.08 \\
\hline \multicolumn{9}{|c|}{ Main streets of districtsignificance } \\
\hline 1 & A.Kukoby & 2 & 0.8 & 0 & 0 & 0 & 0 & 0 \\
\hline 2 & Balakina & 2 & 1.6 & 9 & 7 & 0 & 1 & 0 \\
\hline 3 & Veresny 23 & 2 & 1.1 & 0 & 0 & 0 & 0 & 0 \\
\hline 4 & V.Chor-novola & 2 & 0.5 & 10 & 7 & 0 & 0 & 0 \\
\hline 5 & Ger,ATO & 2 & 3 & 2 & 2 & 0 & 0 & 0 \\
\hline 6 & GeroivStalingradu & 2 & 0.8 & 0 & 0 & 0 & 0 & 0 \\
\hline 7 & Ger,chornobylciv & 2 & 0.7 & 5 & 3 & 8 & 1 & 0 \\
\hline 8 & D.Koryaka & 2 & 0.7 & 21 & 8 & 0 & 0 & 0 \\
\hline 9 & Dovzenka & 2 & 0.4 & 0 & 0 & 4 & 0 & 0 \\
\hline 10 & Kagamlyk & 2 & 2 & 12 & 3 & 2 & 0 & 2 \\
\hline 11 & Koz.Volod & 2 & 0.5 & 15 & 2 & 0 & 1 & 0 \\
\hline 12 & Kotlyarevs & 2 & 0.5 & 7 & 0 & 0 & 0 & 1 \\
\hline 13 & Levanevsk & 2 & 0.5 & 10 & 5 & 0 & 0 & 0 \\
\hline 14 & Lugova & 2 & 2.7 & 0 & 0 & 0 & 0 & 0 \\
\hline 15 & Monastyrs & 2 & 1.1 & 7 & 3 & 3 & 0 & 0 \\
\hline 16 & Nyzhnoml & 2 & 1.3 & 13 & 5 & 0 & 0 & 0 \\
\hline 17 & Nikitchenk & 2 & 1.2 & 10 & 0 & 0 & 0 & 0 \\
\hline 18 & O.Gonchar & 2 & 1.7 & 35 & 7 & 0 & 2 & 1 \\
\hline 19 & P.Myrnogo & 2 & 1 & 10 & 7 & 0 & 0 & 0 \\
\hline 20 & Panyanka & 2 & 1.4 & 15 & 8 & 12 & 0 & 0 \\
\hline 21 & PatriarhaM & 2 & 2.1 & 29 & 13 & 0 & 2 & 1 \\
\hline 22 & Pivdenna & 2 & 0.8 & 7 & 4 & 0 & 0 & 1 \\
\hline 23 & Pushkina & 2 & 3.2 & 15 & 5 & 10 & 1 & 0 \\
\hline 24 & R.Kyryche & 2 & 1.2 & 15 & 8 & 0 & 1 & 0 \\
\hline 25 & Sakko & 2 & 2.1 & 11 & 7 & 10 & 1 & 2 \\
\hline 26 & S.Petlury & 2 & 2.4 & 19 & 8 & 5 & 0 & 2 \\
\hline 27 & S.Halturin & 4 & 0.7 & 3 & 0 & 0 & 0 & 0 \\
\hline 28 & Stritenska & 2 & 1.9 & 16 & 9 & 0 & 1 & 2 \\
\hline 29 & Shvedska & 2 & 1.2 & 5 & 0 & 3 & 1 & 0 \\
\hline 30 & Shevchenk & 4 & 2.1 & 21 & 12 & 15 & 2 & 1 \\
\hline To & & & 41.2 & 322 & 133 & 72 & 14 & 13 \\
\hline & for $1 \mathrm{~km}$ & & & 7.82 & 3.23 & 1.75 & 0.34 & 0.32 \\
\hline
\end{tabular}


Table 5 Comparison of normative requirements for placement of planting elements along the street and road network of settlements in Ukraine and in foreign countries

\begin{tabular}{|c|c|c|c|c|c|c|c|c|c|c|c|}
\hline \multirow{4}{*}{$\begin{array}{l}\text { Elements of streets } \\
\text { and roads, buildings } \\
\text { and structures, } \\
\text { objects of engineering } \\
\text { improvement }\end{array}$} & \multicolumn{3}{|c|}{ Ukraine } & \multicolumn{2}{|c|}{ Queensland, Australia } & Poland & \multicolumn{4}{|c|}{ Sweden } & \multirow{4}{*}{$\begin{array}{c}\text { Denmark } \\
\\
\\
\text { Project } \\
\text { values }\end{array}$} \\
\hline & \multicolumn{10}{|c|}{ Minimum horizontal distance from the building, structure or furniture } & \\
\hline & \multicolumn{2}{|c|}{$\begin{array}{l}\text { To the middle of } \\
\text { tree trunk with a } \\
\text { crown }\end{array}$} & \multirow{2}{*}{$\begin{array}{l}\text { To the } \\
\text { edge of } \\
\text { shrub }\end{array}$} & \multirow{2}{*}{$\begin{array}{l}\text { No frangible } \\
\text { vegetation } \\
\text { (tree) }\end{array}$} & \multirow{2}{*}{$\begin{array}{l}\text { Frangible } \\
\text { vegetation } \\
\text { (shrub) }\end{array}$} & \multirow[t]{2}{*}{ Project values } & \multirow{2}{*}{$\begin{array}{c}\text { Very } \\
\text { small } \\
\text { tree }\end{array}$} & \multirow{2}{*}{$\begin{array}{c}\text { Small } \\
\text { tree }\end{array}$} & \multirow{2}{*}{$\begin{array}{c}\text { Middle } \\
\text { tree }\end{array}$} & \multirow{2}{*}{$\begin{array}{l}\text { Large } \\
\text { tree }\end{array}$} & \\
\hline & $\begin{array}{l}\text { up to } \\
4 \mathrm{~m}\end{array}$ & $\begin{array}{c}\text { more } \\
\text { than } 4 \mathrm{~m}\end{array}$ & & & & & & & & & \\
\hline Building of structure & 3.0 & 5.0 & 1.0 & & & 4 & \multicolumn{4}{|c|}{$7(5.5 *) ;$ narrow crown $4(3)$} & \\
\hline $\begin{array}{l}\text { Tramway or the trolley } \\
\text { line wire }\end{array}$ & 2 & 3 & 0.5 & & & & & & & & \\
\hline $\begin{array}{l}\text { Sidewalk, park- or } \\
\text { bikeway }\end{array}$ & 0.7 & 0.7 & 0.5 & $1(10) * *$ & $0.5 \mathrm{c}$ & & 1.0 & & 1.5 & $1.5-2$ & \\
\hline Edge of roadway & 1 & 3.0 & 0.5 & & & 3 & 1.0 & 1.5 & 2.0 & $2-2.5$ & $\begin{array}{c}2.5, \text { small } \\
\text { tree: } 1.5-2.5\end{array}$ \\
\hline $\begin{array}{l}\text { Lighting, the tram, the } \\
\text { bridge support and the } \\
\text { overpass }\end{array}$ & 1.5 & 3.0 & 0.5 & $\begin{array}{c}5(10- \\
\text { lighting } \\
\text { supports) }\end{array}$ & $\begin{array}{c}5(1 \mathrm{c}- \\
\text { lighting } \\
\text { supports }) \\
\end{array}$ & & & & & & \\
\hline Slope, terraces, etc & 1.0 & 1.0 & - & & & & & & & & \\
\hline Retaining wall & 2.0 & 3.0 & 0.5 & 5.0 & 0.5 & & & & & & \\
\hline \multicolumn{12}{|l|}{ Underground services: } \\
\hline - gas pipeline & 1.5 & 2.0 & - & $3.5 * * *$ & $2 * * * *$ & $\begin{array}{c}0.5 \text { (low and } \\
\text { average gas } \\
\text { pre-sure) } 1.5 \text { for } \\
\text { very large tree }\end{array}$ & & & & & \\
\hline - thermal network & 1.5 & 2.0 & - & \multirow{5}{*}{$\begin{array}{l}4 * * * \text { under- } \\
\text { ground } \\
\text { services, } \\
6^{* * *-} \\
\text { drainage }\end{array}$} & \multirow{5}{*}{$2 * * * *$} & 2.5 & & & & & \\
\hline - sewerage & 1.5 & 2.0 & - & & & 2.5 & & & & & \\
\hline - plumbing, drainage & 1.0 & 2.0 & - & & & 2.0 & & & & & \\
\hline $\begin{array}{l}\text { - power, } \\
\text { communication cable }\end{array}$ & 1.0 & 2.0 & - & & & 2.0 & & & & & \\
\hline $\begin{array}{l}\text { - cable of electrical } \\
\text { networks }\end{array}$ & 1.0 & 2.0 & - & & & \multirow[t]{2}{*}{1.5} & & & & & \\
\hline Noise barriers & & & & $1.5 \mathrm{c}$ & $1 \mathrm{c}$ & & & & & & \\
\hline Road signage & & & & $\begin{array}{l}10 \text { ensure } \\
\text { sight } \\
\text { distance } \\
\text { triangle }\end{array}$ & $\begin{array}{l}\text { sigh light } \\
\text { triangle max } \\
\text { height } 500 \mathrm{~m}\end{array}$ & & & & & & \\
\hline Air electrical networks & \multicolumn{3}{|c|}{ PYE } & \multicolumn{2}{|c|}{ RLM } & PN-E-051001 & & & & & \\
\hline till 20 & & $2 \mathrm{c}$ & - & $7 \mathrm{c}$ & $4 \mathrm{c}$ & $2.7 \mathrm{c}$ & & & & & \\
\hline $35-110$ & & $3 \mathrm{c}$ & - & \multirow{4}{*}{$10 \mathrm{c}$} & \multirow{4}{*}{$6 \mathrm{c}$} & $4 \mathrm{r}$ & & & & & \\
\hline $150-220$ & & $4 \mathrm{c}$ & - & & & $4 c$ & & & & & \\
\hline $350-500$ & & $5 \mathrm{c}$ & - & & & $75 c$ & & & & & \\
\hline \multirow[t]{2}{*}{750} & & $8 \mathrm{c}$ & - & & & $1.5 \mathrm{c}$ & & & & & \\
\hline & \multicolumn{11}{|c|}{ Minimum vertical distance to the crown of tree, $\mathrm{m}$} \\
\hline Roadway & \multirow{3}{*}{\multicolumn{3}{|c|}{ Traffic clearance }} & $6 c$ & - & $\begin{array}{c}4.7(\mathrm{~A}, \mathrm{~S} \text { or } \mathrm{GP}) \\
4.6(\mathrm{G} \text { or } \mathrm{Z}) \\
4.5(\mathrm{~L} \text { and } \mathrm{D})\end{array}$ & & & 4.7 & & 4.2 \\
\hline Bikeway & & & & $2.7 \mathrm{c}$ & - & 2.5 & & & 2.6 & & $2.3-2.8$ \\
\hline Sidewalk & & & & $2.4 \mathrm{c}-$ & - & 2.5 & & & 2.6 & & 2.7 \\
\hline
\end{tabular}

* Crown tree diameter less than $4 \mathrm{~m}$.

** Trees above $15 \mathrm{~m}$, characterized by the risk of falling branches or seeds.

*** All vegetation with height in maturity $>3.5 \mathrm{~m}$.

**** All vegetation with height in maturity $\leq 3.5 \mathrm{~m}$.

$\mathrm{c}$ - distance to the crown of the plant.

$\mathrm{m}$ - distance to the middle of the trunk of the plant.

Roads in Poland are divided into classes: A - freeways, S - high speeds, GP - main streets of accelerated traffic, GZ - main streets, L - local streets and D - passages. 
The distance from the edge of the roadway to the tree in Ukraine is similar to these distances in Poland, Sweden and Denmark. Only in Poland the distance should be $3 \mathrm{~m}$ regardless of the size of the tree, and in Ukraine such distance is only for trees with a crown more than $4 \mathrm{~m}$, and for trees with a crown less than $4 \mathrm{~m}$, this distance should be $1 \mathrm{~m}$. In Queensland the distance to trees is much longer than in Ukraine and is $9.15 \mathrm{~m}$, and for shrubs it coincides with the Ukrainian one $0.5 \mathrm{~m}$.

In Sweden the distance from the roadway to the tree is determined according to the size of the tree: a large tree - 2 - $2.5 \mathrm{~m}$; a middle tree - $2 \mathrm{~m}$; a small tree - $1.5 \mathrm{~m}$; very small tree $-1 \mathrm{~m}$ (Fig. 11).

In Denmark (Table 6) the distance to the fixed objects from the roadway is offered to determine depending on the speed of movement. The green fence is performed $2.8 \mathrm{~m}$ high.

In Queensland (Australia), a "clean zone» with a total width of 9.15 meters is allocated. It can accommodate only a lawn, a width of 0.5 to $2.25 \mathrm{~m}$. Further there is a strip of width from 6.9 to $8.65 \mathrm{~m}$, on which can be placed shrubs height up to $0.5 \mathrm{~m}$ (Fig. 12).

After this strip can already be placed trees. A "clean zone" is needed to avoid a frontal collision of a car with a trunk of a tree in a sudden drift. In the case of strong lateral skidding the strip from the shrub significantly reduces the impact hit or it will make it impossible at all.

In Sweden the term "safety zone" is defined as the territory outside the roadway along the road, which should be free of physical obstacles in the form of solid objects. The size of safety zone varies depending on the calculated

Table 6 The dependence of the minimum distance from the edge of the roadway to stationary objects (Denmark)

\begin{tabular}{lc}
\hline Speed $(\mathrm{km} / \mathrm{h})$ & $\begin{array}{r}\text { The minimum distance to fixed } \\
\text { objects (including trees })(\mathrm{m})\end{array}$ \\
\hline $70-80$ & 3.0 \\
$50-60$ & 1.0 \\
$30-40$ & 0.5 \\
$10-20$ & 0.25 \\
\hline
\end{tabular}
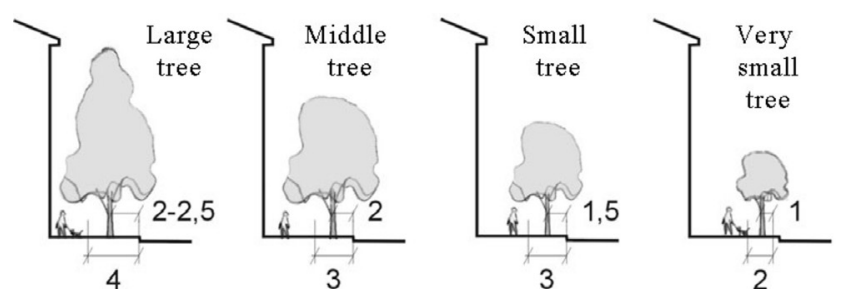

Fig. 11 Distance from the tree to the road section of the street in Sweden (Vägar, 2004)

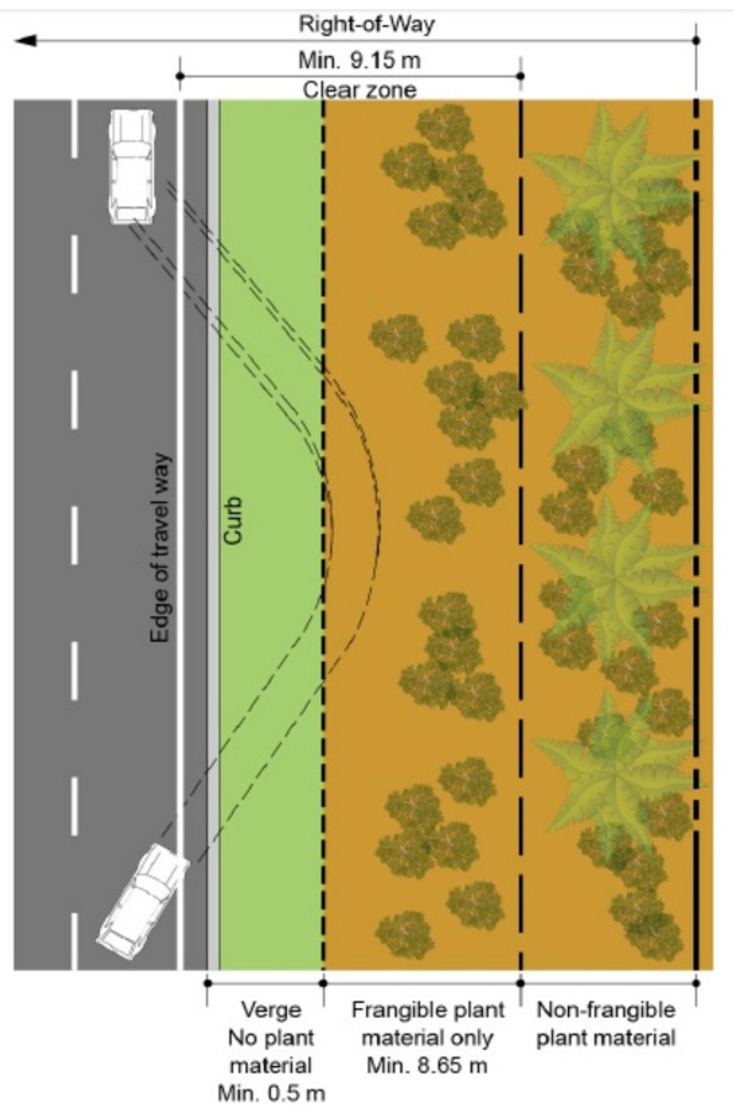

Fig. 12 "Clean zone", Queensland (Australia)

speed of movement and the radius of the horizontal curve (Table 7). Objects should not be in the navel area if they are not fenced with impact protections. Trees with a diameter of more than $100 \mathrm{~mm}$ and $1.20 \mathrm{~m}$ above ground should not be placed in the security zone.

In Denmark, there is also the term "safety zone", its width is similar to width in Sweden, but there are some minor differences, see Fig. 13.

The distance from the mast and the support of the lighting network, tram, bridge pillar and trestle to the tree in

Table 7 Width of the safety zone in Sweden (outside the curve /inside the curve)

\begin{tabular}{lcccc}
\hline \multirow{2}{*}{$\mathrm{R}$} & \multicolumn{4}{c}{$\mathrm{V}, \mathrm{km} / \mathrm{h}$} \\
& 50 & 70 & 90 & 110 \\
\hline$\geq 1000$ & 3 & 7 & 9 & 11 \\
800 & $3 / 3$ & $8 / 6$ & $10 / 8$ & $14 / 8$ \\
700 & $3 / 3$ & $8 / 6$ & $11 / 7$ & \\
600 & $3 / 3$ & $8 / 6$ & $12 / 6$ & \\
500 & $4 / 2$ & $9 / 5$ & $13 / 5$ & \\
400 & $4 / 2$ & $10 / 4$ & & \\
300 & $5 / 1$ & $11 / 3$ & & \\
200 & $5 / 1$ & & & \\
\hline
\end{tabular}




\begin{tabular}{|c|c|c|c|c|c|c|c|c|c|c|}
\hline \multicolumn{11}{|l|}{ Width of the safety zone } \\
\hline$V_{p}(\mathrm{~km} / \mathrm{h})$ & 40 & 50 & 60 & 70 & 80 & 90 & 100 & 110 & 120 & 130 \\
\hline $\begin{array}{l}\text { Horizontal curve }(\mathrm{m}) \\
\text { radius }\end{array}$ & \multicolumn{10}{|c|}{ Requirements for the width of the safety zone b on a flat terrain } \\
\hline$\geq 1.000$ & 2,0 & 3,0 & 4,0 & 5,0 & 6,0 & 7,0 & 8,0 & 9,0 & 10,0 & 11,0 \\
\hline 900 & 2,2 & 3,6 & 4,8 & 6,0 & 7,2 & 8,4 & 9,6 & 10,8 & & \\
\hline 800 & 2,4 & 3,6 & 4,8 & 6,0 & 7,2 & 8,4 & 9,6 & 11,6 & & \\
\hline 700 & 2,4 & 3,6 & 4,8 & 6,5 & 7,8 & 9,1 & 10,4 & 13,0 & & \\
\hline 600 & 2,4 & 3,9 & 5,2 & 6,5 & 7,8 & 9,1 & 11,2 & & & \\
\hline 500 & 2,6 & 3,9 & 5,2 & 7,0 & 8,4 & 10,3 & 12,0 & & & \\
\hline 400 & 2,8 & 4,2 & 5,6 & 7,0 & 9,0 & 11,0 & & & & \\
\hline 300 & 3,0 & 4,5 & 6,4 & 8,0 & 9,5 & & & & & \\
\hline 200 & 3,4 & 5,1 & 7,2 & & & & & & & \\
\hline 100 & 4,8 & 7,5 & & & & & & & & \\
\hline
\end{tabular}

Fig. 13 The width of the safety zone along the road and outside of the horizontal curve on the flat terrain

Ukraine is much smaller than in Queensland. In Ukraine it is from $1.5 \mathrm{~m}$ to $3 \mathrm{~m}$, and in Queensland - $5 \mathrm{~m}$, and from the support of lighting - $10 \mathrm{~m}$. For shrubs this distance is the same for Ukraine and for Queensland.

The distance from the sole or the inner edge of the retaining wall in Ukraine is also significantly lower than in Queensland. In Ukraine - from $2 \mathrm{~m}$ to $3 \mathrm{~m}$, and in Queensland - not less than $5 \mathrm{~m}$.

The distance from underground networks to the elements of landscaping in Queensland and Poland is much higher than in Ukraine. It is in Ukraine from $1 \mathrm{~m}$ to $1.5 \mathrm{~m}$ for trees with crown less than $4 \mathrm{~m}$, and $2 \mathrm{~m}$ for trees with crown more than $4 \mathrm{~m}$, and in Queensland for trees the distances vary from 3.5 to $6 \mathrm{~m}$. There is also a limit to planting shrubs - at least $2 \mathrm{~m}$, and in Ukraine there are no such restrictions. In Poland the distance from underground networks is also bigger - basically $2.5 \mathrm{~m}$.

The distance from the road signs to the tree trunk in Queensland is at least $10 \mathrm{~m}$.

The distance from the air power supply to the elements of landscaping in Ukraine is almost the same as in Poland and much less than in Queensland. So in Ukraine this value varies from 2 to $8 \mathrm{~m}$ to the crown of wood, in Poland it is from $2.7 \mathrm{~m}$ to $7.5 \mathrm{~m}$, and in Queensland from $7 \mathrm{~m}$ to 10 $\mathrm{m}$ to trees (not damaged vegetation) and from $4 \mathrm{~m}$ to $6 \mathrm{~m}$ to shrubs. In Ukraine the distance to shrubs is not limited.

The minimum vertical distance from the travel section, the pavement and the bicycle path to the crown of a tree in Ukraine is limited to the size of the movement without specifying the exact values. In Queensland (Road Landscape Manual, 2013) the distance on the driving section is $6 \mathrm{~m}$, on the bicycle path $-2.7 \mathrm{~m}$, on the sidewalk - $2.4 \mathrm{~m}$. In Poland the vertical distance to the crown depends on the road class (street) and varies from $4.7 \mathrm{~m}$ to $4.5 \mathrm{~m}$. For the cycling path and the sidewalk this distance is the same - $2.5 \mathrm{~m}$. In Sweden and Denmark the values of the vertical up to the crown of the tree are similar to the Polish, but do not depend on the class of roads (streets). In Sweden the overall dimensions are $4.7 \mathrm{~m}$ and $4.2 \mathrm{~m}$ in Denmark. The dimensions for the sidewalk and bicycle paths in Sweden are the same - $2.6 \mathrm{~m}$, and in Denmark it differs: for the cycling track varies from $2.3 \mathrm{~m}$ to $2.8 \mathrm{~m}$, and for the sidewalk $-2.7 \mathrm{~m}$.

\section{Foreign experience of road greening}

In this part of the study the planting of streets of foreign countries was explored using the Google maps geo-information system, which contains photography of many streets of the world. Berland and Lange have established that virtual surveys in Street View may be suitable for generating some types of street tree data or updating existing data sets more efficiently than field surveys (Berland and Lange, 2017).

Due to the large number of survey materials, we give only the main differences and advantages of planting the streets of foreign countries from the Ukrainian ones. In foreign countries shrubs and flowers are often used in the separation lane to better segregate traffic flows and to prevent dazzling lights of oncoming vehicles (Figs. 14 and 15).

In tight conditions close to the travel section are planted trees with small diameter of trunk (Blumentrath and Tveit, 2014; Hopkinson et al., 2016) (Fig. 15).

In Denmark individually standing trees close to the roadway offer enclose (Fig. 16).

\section{Conclusions}

Consequently, there is a need to improve the state of Ukraine streets greening. We can highlight the following recommendations to do this:

1. To develop a normative document detailing the requirements for greening the streets of Ukraine.

2. To improve in the norms of Ukraine the classification of plants taking into account not only the diameter of crown and height, but also the diameter of trunk, to design the placement of trees (Joye et al., 2010).

3 . To set the fence of trees that grow closer to the roadway than provided by the norms (Fig. 16).

4. To remove trees that grow very close to the roadway, where the enclosure does not fit.

5. To apply the planting of bushes (Figs. 17 and 18) and small trees with a diameter of trunk up to 10 $\mathrm{cm}$ in tight conditions and in areas of streets without planting. 

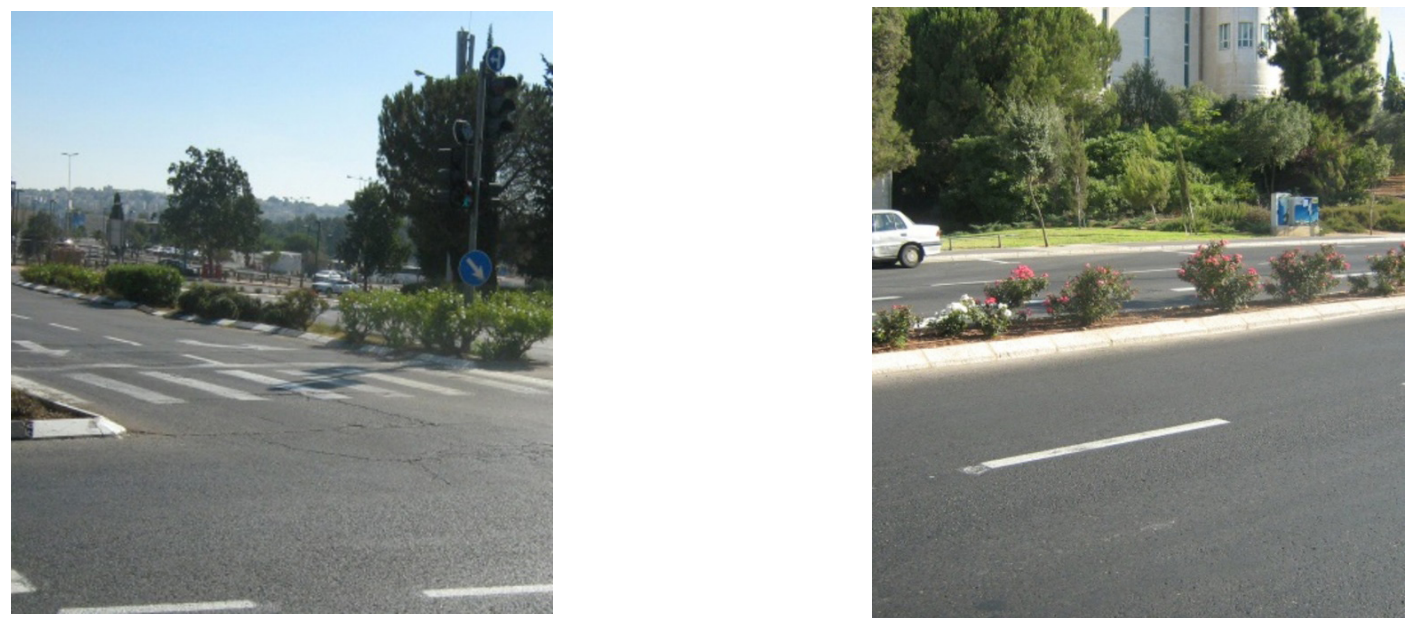

Fig. 14 Planting shrubs and flowers on the dividing strip, Israel
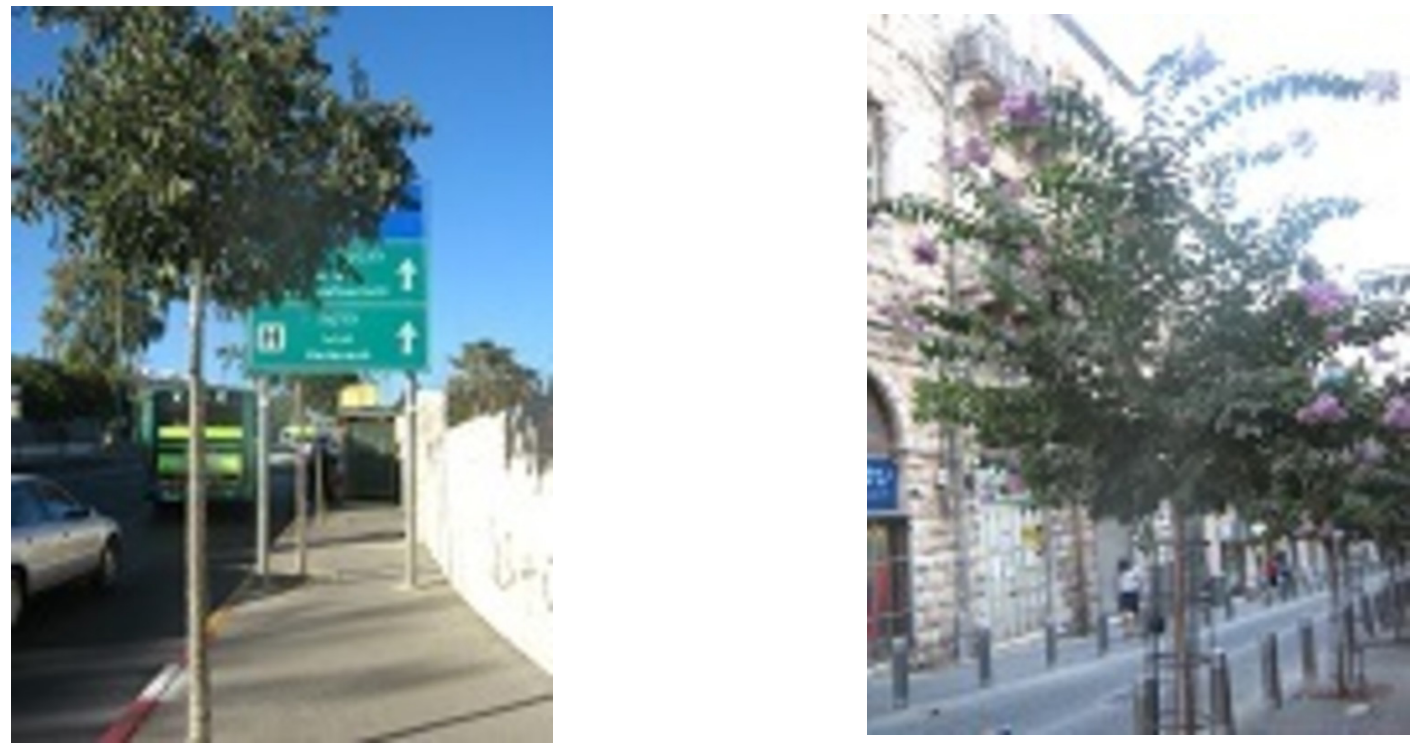

Fig. 15 Planting trees with a narrow trunk close to the roadway, Israel
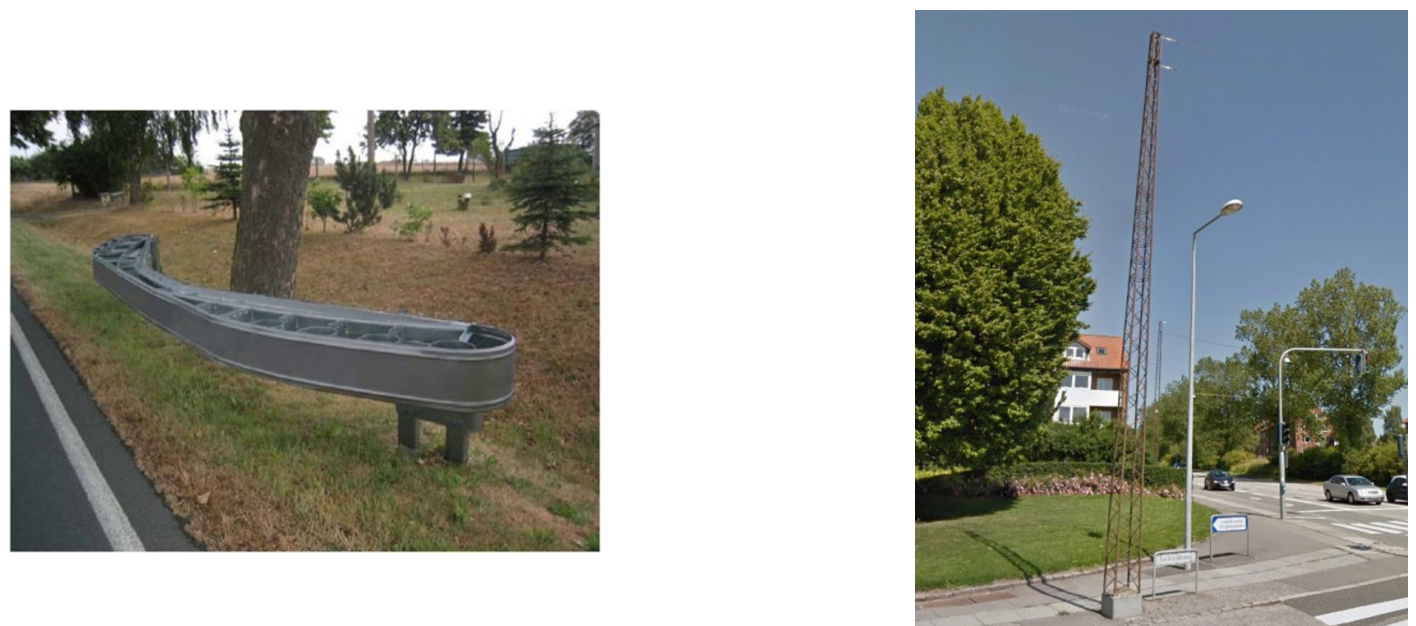

Fig. 16 Denmark: a - an example of fencing the tree growing in the safety zone; $b$ - the lighting pillar made of metal farms 


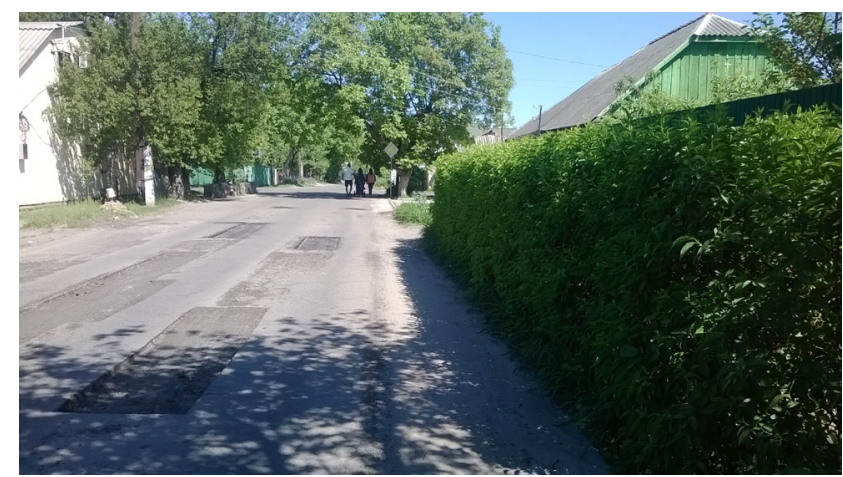

Fig. 17 Planting of bushes along the street, view from the side of the roadway, street Bayana (Poltava, Ukraine)

6. To replace concrete pillars of lighting that are located closer than $3 \mathrm{~m}$ to the traffic area with light metal structures (Fig. 16).

7. When planting trees, to select unsightly varieties and, when operating, constantly identify branches and trees that can break and remove them..

8. To select and recommend varieties of plantations resistant to unsatisfactory ecological conditions: air pollution and salt, which is sprinkled streets in winter.

\section{References}

Akbar, K. F., Hale, W. H. G., Headley, A. D. (2003) "Assessment of scenic beauty of the roadside vegetation in northern England", Landscape and Urban Planning, 63(3), pp. 139-144.

https://doi.org/10.1016/S0169-2046(02)00185-8

Babkov, V. (1993) "Dorozhnye uslovija i bezopasnost' dvizhenija" (Road conditions and traffic safety), Transport, Moscow, Russia. (in Russian)

Badrulhisham, N., Othman, N. (2016) "Knowledge in Tree Pruning for Sustainable Practices in Urban Setting: Improving Our Quality of Life", Procedia - Social and Behavioral Sciences, 234, pp. 210-217. https://doi.org/10.1016/j.sbspro.2016.10.236

Baldauf, R. (2017) "Otsenka vliyaniya zelenykh nasazhdeniy na bezopasnost' dorozhnogo dvizheniya" (Roadside vegetation design characteristics that can improve local, near-road air quality), Transportation Research Part D: Transport and Environment, 52, pp. 354-361. (in Ukrainian)

https://doi.org/10.1016/j.trd.2017.03.013

Berland, A., Lange, D. A. (2017) "Google Street View shows promise for virtual street tree surveys", Urban Forestry \& Urban Greening, 21, pp. $11-15$.

https://doi.org/10.1016/j.ufug.2016.11.006

Blumentrath, C., Tveit, M. S. (2014) "Visual characteristics of roads: A literature review of people's perception and Norwegian design practice", Transportation Research Part A: Policy and Practice, 59, pp. 58-71.

https://doi.org/10.1016/j.tra.2013.10.024

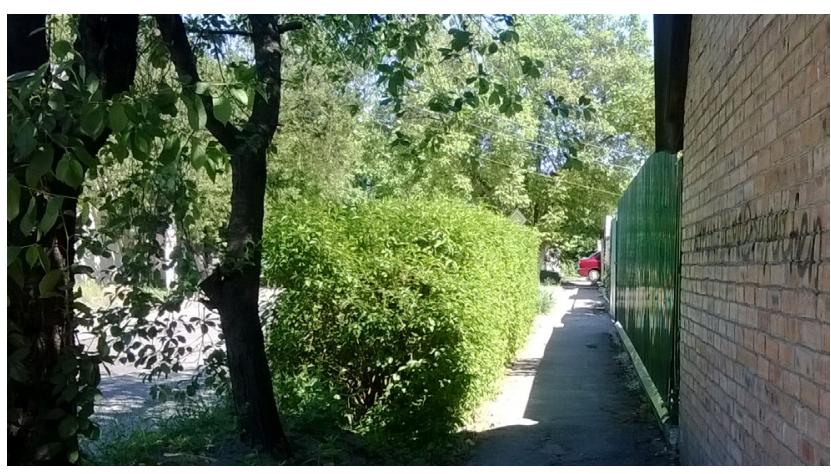

Fig. 18 Planting of bushes along the street, view from the sidewalk, street Bayana (Poltava, Ukraine)

\section{Acknowledgment}

The work is connected with the research program of Highways, Geodesy, Land management and Rural buildings department of Poltava National Technical Yuri Kondratyuk University (Ukraine)- "Improvement of highways and street and road network" (Project ID: 0114U000354).

Department of Information and Analytical Support of the National Police of Ukraine (2017) "Statystyka avarijnosti v Ukrayiniza 8 misyaciv 2017 roku" (Statistics of accidents in Ukraine for 8 months of 2017), Department of Information and Analytical Support of the National Police of Ukraine, Kiyv, Ukraine. (in Ukrainian)

Fitzpatrick, C. D. (2013) "The Effect of Roadside Elements on Driver Behavior and Run-Off-the-Road Crash Severity", Masters Theses, University of Massachusetts Amherst. [online] Available at: https:// scholarworks.umass.edu/cgi $/$ viewcontent.cgi? article $=2174 \&$ context=theses [Accessed: 10 January 2020]

Hasan, R., Othman, N., Ismail, F. (2016a) "Roadside Tree Management in Selected Local Authorities for Public Safety", Procedia - Social and Behavioral Sciences, 234, pp. 218-227. https://doi.org/10.1016/j.sbspro.2016.10.237

Hasan, R., Othman, N., Ahmad, R. (2016b) "Tree Preservation Order and its Role in Enhancing the Quality of Life", Procedia - Social and Behavioral Sciences, 222, pp. 493-501.

https://doi.org/10.1016/j.sbspro.2016.05.140

Hopkinson, L. C., Davis, E., Hilvers, G. (2016) "Vegetation cover at right of way locations", Transportation Research Part D: Transport and Environment, 43, pp. 28-39.

https://doi.org/10.1016/j.trd.2015.12.011

Jermołowicz, P. (2016) "Zieleń przydrożna w pasie drogowym i na krawędziach jezdni w aspekcie zagrożeń w ruchu drogowym" (Roadside greenery in the mini-edge road lane in the aspect of traffic dangers), Magazyn Autostrady, 6, pp. 55-60. [online] Available at: https://www.inzynieriasrodowiska.com.pl/images/ pdf_encyklopedia/zielen_przydrozna_w_pasie_drogowym.pdf [Accessed: 10 January 2020] (in Polish) 
Joye, Y., Willems, K., Brengman, M., Wolf, K. (2010) "The effects of urban retail greenery on consumer experience: Reviewing the evidence from a restorative perspective", Urban Forestry \& Urban Greening, 9(1), pp. 57-64.

https://doi.org/10.1016/j.ufug.2009.10.001

Kadir, M. A. A., Othman, N. (2012) "Towards a Better Tomorrow: Street Trees and Their Values in Urban Areas", Procedia - Social and Behavioral Sciences, 35, pp. 267-274.

https://doi.org/10.1016/j.sbspro.2012.02.088

Khomyak, Y. V., Goncharenko, F. P., Kopilevych, S. L. (1990) "Inzhenernoye oborudovaniye avtomobil'nykh dorog" (Highway Engineering Equipment), Transport, Moscow, Russia. (in Russian)

Ministry of Fuel Energy of Ukraine (2017) "DBN V.2.3-5: 2017.Vulyci ta dorogy naselenyx punktiv" (Streets and roads of settlements), Minpalyvenergo Ukrayiny, Kiyv, Ukraine. (in Ukrainian)

Mok, J. H., Landphair, H. C., Naderi, J. R. (2006) "Landscape improvement impacts on roadside safety in Texas", Landscape and Urban Planning, 78(3), pp. 263-274.

https://doi.org/10.1016/j.landurbplan.2005.09.002

Naderi, J. R., Kweon, B. S., Meghalel, P. (2008) "The street tree effect and driver safety", ITE Journal on the web, 78(2), pp. 69-73. [online] Available at: https://www.researchgate.net/publication/292767085_The_street_tree_effect_and_driver_safety [Accessed: 10 January 2020]

Ornatskij, N. (1986) "Blagoustrojstvo avtomobil'nyh dorog" (Highway Improvement), Transport, Moscow, Russia. (in Russian)

Parwathaneni, R. (2016) "Effect of roadside vegetation on driver behavior", Masters Theses, Vellore Institute of Technology University. [online] Available at: https://etd.ohiolink.edu/!etd.send_file?accession $=$ csul $1481555419869409 \&$ disposition $=$ inline [Accessed: 10 January 2020]
Polish Dendrological Society(2016) "Standardy Kształtowania Zieleni Warszawy" (Warsaw Greenery Shaping Standards), Polish Dendrological Society, Warszawa, Poland. (in Polish)

Queensland Government - Department of Transport and Main Roads "Road Landscape Manual (RLM), A Guide to the Planning, Design, Operation and Maintenance of Road Landscape Infrastructure", Queensland Government - Department of Transport and Main Roads, Brisbane, Australia, 2013. [online] Available at: https:// www.tmr.qld.gov.au/business-industry/Technical-standardspublications/Road-landscape-manual.aspx [Accessed: 10 January 2020]

Sardarov, A. (2001) "Arhitektura avtomobil'nyh dorog Belarusi" (Highway architecture of Belarus), PhD Theses, Belarusian State Polytechnical Academy. (in Russian)

Tong, Z., Baldauf, R. W., Isakov, V., Deshmukh, P., Zhang, K. M. (2016) "Roadside vegetation barrier designs to mitigate near-road air pollution impacts", Science of the Total Environment, 541, pp. 920-927.

https://doi.org/10.1016/j.scitotenv.2015.09.067

United Nations Economic Commission for Europe (2018) "Statistical Database Road traffic fatalities and injuries, rate per million inhabitants and rate per 100000 passenger cars by Topic, Measurements", UNECE, Genf, Switzerland. 